\title{
STRATEGIZING CORPORATE ENTREPRENEURSHIP FOR VALUE CREATION AND VALUE CAPTURE
}

Wojciech Dyduch*, Mariusz Bratnicki**

\begin{abstract}
The purpose of this paper is to look at the sources of value creation in organizations. The paper specifically seeks to determine the relations between strategic potential of the organizations, corporate entrepreneurship and value creation. We present a theoretical framework for understanding the link between strategic processes stimulating innovation and entrepreneurship that we see as the sources of value creation and value capture. We test part of this framework through a survey carried out among enterprises in Poland. The research results suggest, that while strategic potential of organizations and the level of corporate entrepreneurship are strongly correlated, there might be some other mechanisms explaining value creation, than just strategic potential nurturing innovation, or corporate entrepreneurship itself. We address the future research intent by offering a broader framework looking at the contextual factors, and specifically the notion of value creation and value capture as mediators between corporate entrepreneurship and performance ${ }^{* * *}$.
\end{abstract}

Keywords: strategic potential, corporate entrepreneurship, value creation, value capture.

JEL Classification: A10, M1.

\section{INTRODUCTION}

There is a variety of research concerning relations between entrepreneurship and performance (Lumpkin \& Dess, 1996; Rauch et al., 2009; Zahra et al., 1999), innovativeness and performance (Rass et al., 2013),

* University of Economics in Katowice. E-mail: dyduch@ue.katowice.pl

** University of Dąbrowa Górnicza. E-mail: mabrat@ue.katowice.pl

**** This paper is the result of the research project "Value creation and value capture in entrepreneurial organizations" supported financially by the National Science Center (NCN) Poland (grant no 2015/17/B/HS4/00935). 
innovativeness and value creation (Cooper, 2011), entrepreneurship and value appropriation (Alvarez \& Barney, 2004), value creation and value capture (Chatain \& Zemsky, 2011; Priem \& Swink, 2012; Kivleniece \& Quelin, 2012), value creation, competitiveness and effectiveness (MacDonald \& Ryall, 2004), value creation and strategic relationships (Subramanian et al., Xia 2014), strategy and value creation (Foss \& Lindenberg, 2013), complementary assets and value capture (Grimpe \& Hussinger, 2013), value creation, value capture and destroying value (Bowman \& Ambrosini, 2010) or value creation while avoiding its destroying (Gauthier, 2014). To-date however, there is no exhaustive research offering a comprehensive model taking into consideration complex relations between the presented constructs. Particularly, while the attention is paid to innovativeness as a dimension of entrepreneurship (Miller, 1983), and a lot of research focuses on the link between the level of innovativeness and performance (Cooper, 2011), not much discussion is going on about the moderating role of value creation and capture mechanisms that influence this relation. It is therefore important to focus not just on the value creation as a result of entrepreneurial processes, and its relations with performance, but also on the influence of value capture as well as appropriation mechanisms and strategies determining the amount of value that stays in the organization and results in above-average outcomes (high performance, competitive advantage, organization's redesign, new innovations, etc.; Alvarez \& Barney, 2004). Additionally, the literature addresses recent call for taking into consideration the contextual factors in the value creation and value capture processes, such as the characteristics of sector/environment, as well as the characteristics of the organization itself (James et. al., 2013).

The link between entrepreneurship and performance seems natural, particularly from the innovativeness perspective, being one of the entrepreneurship dimensions (Miller, 1983). However, the innovation itself does not create value. It is commercialization of the innovation, i.e. the processes of strategic entrepreneurship that translate the innovative product into value (Bilton \& Cummings, 2010). We assume however, that value is created not just from innovation, but from other strategic and entrepreneurial processes driving the organizations, that result in novelty understood as innovative organizational design, new business model, new strategic approach, exploiting opportunities, etc. (Amit \& Zott, 2001). 
Some organizations are more entrepreneurial than the others, and they employ creative people, who work long hours to prepare innovative ideas. Still, these particular organizations are not effective, not competitive or lose their longevity (Johns, 2005). The problem to be addressed here is to identify the ability of organizations not just to create value but to capture value, take over value, protect it and avoid its destroying. This paper partially seeks to address these issues, by identifying the relations between the strategic potential of the organizations, corporate entrepreneurship, and value creation. In the first part we present some theoretical findings concerning the discussed constructs. As a result, a theoretical model of relations has been identified. A part of that model, concerning the key concepts of strategic potential, corporate entrepreneurship and value creation is tested in the empirical part of this paper. Following the limitations of this research, we eventually offer a more comprehensive model for analysing the relations between organization's strategic potential, entrepreneurship and value creation processes.

\section{THEORETICAL BACKGROUND}

The notion of value creation can be sometimes understood narrowely, focusing only on customer value, or value created in production (Chatain, 2010). However, the value creating opportunities may be well hidden throughout the whole business model that may result in both positive and negative aspects of value capture (captured value vs. uncaptured value). Therefore, it is essential to identify the elements of potential value creation and capture (eg. the existing business model, value delivery to stakeholders, product design, stakeholders' influence through the business life cycle, tangible and intangible value creation, value destruction, failing to capture value, new business model needed to capture value opportunities) (Yang et al., 2017). This implies the notion of strategic potential, and its significance in the processes of value creation and value capture.

We understand the strategic potential as encompassing five dimensions. First of all, it is the organization's ability to formulate and implement a successful strategy, even in the case of lack of innovation (Pitelis, 2009). Next, the strategic potential focuses on the organization's ability to indicate places of value creation in the value 
chain (Chesbrough \& Rosenbloom, 2002). Third, it is identified with the proper organizational design nurturing innovation (designing structures stimulating creativity, knowledge management, places to work allowing both concentration and lax time, cf. Bilton \& Cummings, 2010). Finally, strategic potential is connected with organization's marketing capabilities to design, propose value for customers and extract it by sales (Desarbo et al., 2005). Recently, there has been some proposition made as to developing strategic potential for bringing more innovation and creating deliberate approach to organization's growth and development (Horth \& Vehar, 2014) by: (a) developing the creative strategy that embraces innovation, (b) focusing on strategic leadership, (c) communicating challenging strategic issues throughout the organization, (d) creating highly diverse teams, (e) provide organization's members with access to creative methods and experiences, (f) designing and building systems that nurture innovations, (g) awarding potential ideas that seem not to fit, spanning boundaries, breaking down barriers for innovation.

We posit, that strategic potential of the organization is a starting point to nurture innovation and stimulate organizational entrepreneurship. There are plenty of approaches and conceptualizations of organizational entrepreneurship (Acs \& Audretsch, 2003), but in the significant number of research, the operationalization of entrepreneurial orientation is used (Anderson et al., 2015), which describes entrepreneurship by innovativeness, proactiveness, risk taking, competitive aggressiveness and autonomy. Other conceptualizations and their operationalizations, e.g. strategic entrepreneurship (Hornsby et al., 2013; Morris et al., 2011), entrepreneurial management (Brown et al., 2001), corporate entrepreneurship (Bilton \& Cummings, 2010) are not commonly used to explain the notion of entrepreneurship. A stream of research indicates entrepreneurial orientation as independent variable (George, 2011; Rauch et al., 2009; Renko et al., 2009; Wiklund \& Shepherd, 2005). Therefore, our research will fit in this vein, applying the conceptualization of entrepreneurial orientation as a reflection of the firm's entrepreneurship level and the dynamic capability strengthening the value creation processes (Gelei, 2012).

Value created through the innovative and entrepreneurial processes is a construct worth having a closer look. As the literature suggests, there is no agreement in understanding and defining value creating processes in organizations (Lepak et al., 2007). This derives from the 
fact, that value represents different concepts for various stakeholders. Organization that attempts to meet its investor and stakeholder expectations functions both as a customer and a supplier, therefore the motives for value creation might be different, often contradictory. Therefore, it is important to apply the stakeholder perspective to this thinking, and assess what are the expectations of particular groups of stakeholders and what importance it bears for value creating processes as well as for reaching above-average results by the organizations (Afuah, 2000). For the purpose of the research however, we stress at the value creation from the customer perspective, looking at how much this group of stakeholders is willing to pay for what the organization offers. The return on sales will be the natural measure of value creation understood this way.

Value creation is typically analysed within the resource-based view, where the important role of developing or taking over dynamic capabilities is stressed (Peteraf \& Barney, 2003; Livengood \& Reger, 2010; Blyler \& Coff, 2003), in relation to higher performance (Helfat, 1997) and with contextual factors responsible for strengthening the dynamic capabilities-value creation link (Ethiraj et al., 2005). Creating value based on valuable, rare, hard to imitate and non-substitutable resources (Talaja, 2012) is defined as a difference between the willingness to pay (the highest value the end user is able to pay) and the cost of opportunity taking (lowest price the supplier sells their resources for) (Brandenburger \& Stuart, 1996). Value creation is also defined as a difference between willingness to pay and the level of use value and exchange value (Bowman \& Ambrosini, 2010). Consequently, increase in the use value (e.g. perception of the customer) translates into organization's value creation, and the increase in exchange value influences the value capture by stakeholders with high purchasing power.

Value creation processes from the resource-based view are often analysed in relation to innovativeness (Balka et al., 2014; Cooper, 2011; Fischer, 2011). Even the most effectively developed innovation will not increase the outcomes, if the entrepreneurial organizations are not able to protect (capture and appropriate) or to increase (take over) significant part of the value created. Recent research points out, that it is enough for organizations to be creative and strategically support the processes of innovativeness and entrepreneurship in order to reach above-average performance (Bilton \& Cummings, 2010). However, entrepreneurial organizations are not always competitive, as part of their value is 
captured by other stakeholders or competitors. Therefore, a call for holistic innovations implementation has been made, covering not just new product or service development, but also changes in the business models, strategies, value building for customers, managerial processes, developing rules for rent appropriation from innovation (Venkatraman $\&$ Henderson, 2008). Optimal level of value creation depends on proper entrepreneurial management, particularly in the context of motivating organization members to take opportunities and reach shared goals (Lindenberg \& Foss, 2011). In order to stimulate that motivation, value creation and reaching above-average results cannot be a goal communicated itself, since it decreases motivation. Value creation processes and above-average performance are reached naturally, when other goals are communicated as priorities (e.g. entrepreneurial attitude, long-term development, innovativeness, high-level customer service (Foss \& Lindenberg, 2013).

Value capture is a significant construct usually accompanying value creation (Chatain \& Zemsky, 2011; Priem \& Swink, 2012; Kivleniece \& Quelin, 2012; Bowman \& Ambrosini, 2010). It is defined as a main objective of the competition strategies (Chen \& Miller, 2015). Value capture depends on the position, purchasing power and dependencies between stakeholders (Skilton, 2014). Some enterprises are capable of capturing more value than the others, although they create less value. This led to an interest in extending the resource-based perspective with the assessing the ability of using resources in a way outperforming the stakeholders (Barney \& Arikan, 2001). Consequently, the interest of scholars was focused on researching the ability of top management to proper coordinating, bundling and deploying resources in order to capture most of the created value (Morrow et al., 2007; Sirmon et al., 2007). Empirical data reveals, that for example in the video games and console production sector, the producer captures $20 \%$ of the created value, while software developer and publisher takes $40 \%$, and the distributor and retail seller $10 \%$ and $30 \%$ respectively (Johns, 2005). Looking e.g. at Apple one can say, that the company captures majority of the value created. Components are produced in Asian markets, but due to keeping core functions in-house (design, use value, marketing, software development, product portfolio management, supply chain control) the company has the power of taking over part of the value from its sellers (Kraemer et al., 2008). Some analyses from the automotive industry show that there is a dramatic difference in value creation and 
value distribution among stakeholders of different companies. It has been also noted, that while innovation-based inputs may not change over time, the incremental value creation is increasing through value capture (producing the some output with less input), resource saving, quality improvements or the combination of all the factors (Lieberman \& Balasubramanian, 2007).

Similarly, it has been observed, that in the automotive and airplane industry, shareholders capture only a small fraction of the value created by the firm, whereas other stakeholders are capturing most - if not all - of the gains (Hoffmann \& Henkel, 2015). Therefore, a shareholder-centric approach to analysing value creation and appropriation may prove insufficient, and there is a need for a stakeholder perspective to analysing value creation and capture processes (Garcia-Castro \& Aguilera, 2015).

Recently, the concepts of value creation and value capture, usually bundled together as one construct, have been separated through an empirical test (Tescari \& Brito, 2016). It has been noted, that value creation can be unravelled by the identification of its sources: intrinsic (set of benefits derived from resources belonging to one party that can be captured by another party), and relational (mutual benefits generated through collaboration between buyers and suppliers). The results suggest the advantages of the relational value, indicating that both sides benefit from the total value created by the relationship, though the degree of the value capture may vary (Tescari \& Brito, 2016).

The ability to capture a lot of value created depends not only on the purchasing power, stakeholder dependency, supply chain control, but also on the nature of resources possessed or controlled (Stevenson \& Jarillo, 1990). Creating value in entrepreneurial processes requires using of intangible resources, as well as complementary resources. Of particular importance are resources required for commercializing innovation such as production feasibility, technology, distribution channels, customer service, brand reputation, expert knowledge (Fischer, 2011). Complementary resources constitute appropriation mechanisms that make it possible for organizations to capture the value created. Among other appropriation mechanisms are operations time, patents, open licensing (West, 2007), secrecy, lead time, priority on the market (James et al., 2013; Fischer, 2011). It is stressed, that creating value in a sustained way is a key condition for sustained capturing (Verdin \& Tackx, 2015). 
Recent research results indicate that the level of competition influences the value sharing processes between distributors and buyers in some particular sectors. Among factors making it possible to capture the value created are resources, organizational capabilities, expert knowledge, specialist knowledge valuable for customers, social capital building, long-term relations with customers, competition between distributors, focusing on end-user needs. Increase in the value created and the level of value captured depends on strategic interactions with other companies (Chatain, 2010).

Following the literature we assume, that the organization's ability to create and capture value will largely depend on its strategic potential built on the following dimensions: (a) the ability to formulate a strategy that will strengthen the value creation processes, (b) the ability to indicate the value creation processes in the value chain, (c) the ability to create the organizational design stimulating value creation processes, (d) marketing capabilities to design, propose value for customers and extract it by sales, (e) network building capabilities both inside and outside of the organization.

Next, we see the strategic potential as an antecedent of organizational entrepreneurship. The dimensions pointed above are the source of stimulating creativity, nurturing innovation and strengthening the organizational entrepreneurship, which in turn can create and capture value. Basing on the discussion above, we have identified a research model that covers three constructs discussed in this section: strategic potential of the organizations, corporate entrepreneurship, and value creation. On the basis of the identified research model, the following hypotheses were formulated:

Hypothesis 1: Strategic potential is positively related to corporate entrepreneurship.

Hypothesis 2: Corporate entrepreneurship influences the value creation processes.

Hypothesis 3: Strategic potential influences the value creation processes. 


\section{RESEARCH METHODOLOGY}

We decided to collect data by means of survey, with the use of a questionnaire. Dimensions of strategic potential, corporate entrepreneurship and value creation were operationalized and presented as variables, whose level was assessed by statements in the questionnaire. The respondents' task was to assess the statements on the 7-point Likert scale. The construct of strategic potential was described by nine statements. They encompassed the organization's ability to formulate successful strategy, even in the case of lack of innovation (Pitelis, 2009), the ability to indicate places of value creation in the value chain (Chesbrough \& Rosenbloom, 2002), proper organizational design nurturing innovation (Bilton \& Cummings, 2010), marketing capabilities to design, propose value for customers and extract it by sales (Desarbo et al., 2005). Corporate entrepreneurship was described by seven statements encompassing opportunity recognition and exploitation on the strategic level (Kuratko \& Audretsch 2009), strategic entrepreneurial orientation (Lumpkin \& Dess, 1996). For value creation we used both objective, financial measures (return on sales), as well as non-financial ones, using the scale items proposed by Antoncic and Hisrich (2003).

The questionnaire has been sent to over 2000 top managers of business organizations operating in Poland. The companies were randomly selected from all sectors of activity. The choice of the transition economy organizations is justified by the drive towards innovation, relatively high speed of change, orientation for creativity and opportunity exploitation. 395 questionnaires qualifying for further empirical analyses were returned. The return rate was relatively high due to phone calls or personal visits in the companies. $50.5 \%$ of organizations were small, $16.1 \%$ medium-sized, and $33.4 \%$ were large corporations. $18.2 \%$ of the researched organizations operate in services, $16 \%$ in trade, $11.1 \%$ are involved in production, $10.7 \%$ operate in the building and constructions sector, $9.7 \%$ deal with finance and insurance. The remaining branches represented less than $10 \%$. For analyzing the data and hypotheses testing, we used IBM SPSS 20 and MPlus 3.0 software. 


\section{RESULTS}

In this part we will present two models, showing the relations between the strategic potential corporate entrepreneurship and value creation. The first model will use subjective, non-financial, perceived measures of value creation. The second will incorporate the financial measure return on sales (ROS) as the indicator of value creation in organizations. In the first case according to the $c^{2}$ value (1501.03) there has not been a proper data-model fit. According to the RMSEA value (0.065) the model is fitting acceptably the data collected, therefore we decided to run the confirmatory factor analysis (Table 1). We have identified statistically significant $(p=0.000)$ and relatively high $(0.830)$ relation between strategic potential of the organizations and corporate entrepreneurship. However, the regression part of the model looks different. There is some positive influence of the strategic potential onto the value creation (0.084) and corporate entrepreneurship onto the value creation (0.287), they are however statistically insignificant $(p>0.1)$. What is more, the coefficient of determination (0.168) indicates, that the value creation processes are explained only partially by the strategic potential and corporate entrepreneurship. Other factors not revealed in this analysis may explain the value creation processes in the researched organizations.

Table 1. Strategic potential and entrepreneurship - confirmatory factor analysis results

\begin{tabular}{|l|l|l|l|}
\hline \multicolumn{5}{|c|}{ Estimates: } \\
\hline VC sub Model RMSEA & 0.065 & ROS Model RMSEA & 0.070 \\
\hline 90\% lower RMSEA & 0.061 & $90 \%$ lower RMSEA & 0.065 \\
\hline 90\% upper RMSEA & 0.068 & $90 \%$ upper RMSEA & 0.075 \\
\hline p-Value RMSEA < 0.05 & 0.000 & p-Value RMSEA < 0.05 & 0.000 \\
\hline \multicolumn{5}{|c|}{ Correlations: } \\
\hline Strategic potential \& corporate entrepreneurship in VC sub model & $0.830(p=0.000)$ \\
\hline Strategic potential \& corporate entrepreneurship in ROS model & $0.835(p=0.000)$ \\
\hline \multicolumn{5}{|c|}{ Regression: } \\
\hline \multicolumn{5}{|c|}{ Corporate entrepreneurship } \\
\hline VC sub & $0.084(p>0.1)$ & VC sub & $0.287(p>0.1)$ \\
\hline ROS & $0.056(p>0.1)$ & ROS & $-0.005(p>0.1)$ \\
\hline
\end{tabular}

Source: own research. 
In the case of the second model using the ROS as an objective measure of value creation, again the $c^{2}$ value (1130.36) indicated improper fit between the obtained data and the model, but the RMSEA value (0.070) let us carry out the confirmatory factor analysis (Fig. 1). Again, in the case of the second model, there is a relatively high (0.835) and statistically significant $(\mathrm{p}=0.000)$ relation between the strategic potential of organizations and the level of corporate entrepreneurship. However, the influence of strategic potential (0.056) and corporate entrepreneurship $(-0.005)$ on the value creation processes is statistically insignificant ( $p>0.01)$. The above results have led us to accept the hypothesis 1 , and reject the hypotheses 2 and 3 .

\section{DISCUSSION}

The relations between strategic potential, entrepreneurship dimensions and value creation, value creation and capture, entrepreneurship and performance with the moderating role of value capture mechanisms and contextual factors, were not covered comprehensively. Literature calls for researching motives and possibilities of value capturing mechanisms and strategies implemented by organizations, and particularly for extending the research models with contextual factors (James et al., 2013), and with entrepreneurial processes (Fischer, 2011).

This paper attempted to look at the relations between strategic potential of organizations, corporate entrepreneurship and value creation and value capture. We tried to describe, and theoretically develop the dimensions of the strategic potential, as well as operationalize them, test them empirically and link with value creation processes. The assumptions in the theoretical part led us to concluding, that nature of strategic potential lies in the following dimensions: formulating a strategy that strengthens the value creation processes, the ability to indicate the value creation processes in the value chain, creating organizational design that stimulates value creation, marketing capabilities to propose value for customers, and network building capabilities.

We posited that the strategic potential built around these dimensions can stimulate the processes of creativity within organizations, that in turn is the source of innovativeness and entrepreneurship. It is the organization that - benefiting from it's strategic potential - is or is 
not able to create value and capture most part of it. This study partly addresses the issue of organizational outcomes. We tried to shift the attention from the dependent variables, such as performance, competitive advantage, and financial outcomes, towards the inner organizational power - strategy that can stimulate entrepreneurship. We posit, that instead of the managerial drive to concentrate on outcomes, organizations should look for the sources of outcomes - that is entrepreneurial ideas born in organization. Then, entrepreneurial ideas will be the source of value creation and value capture.

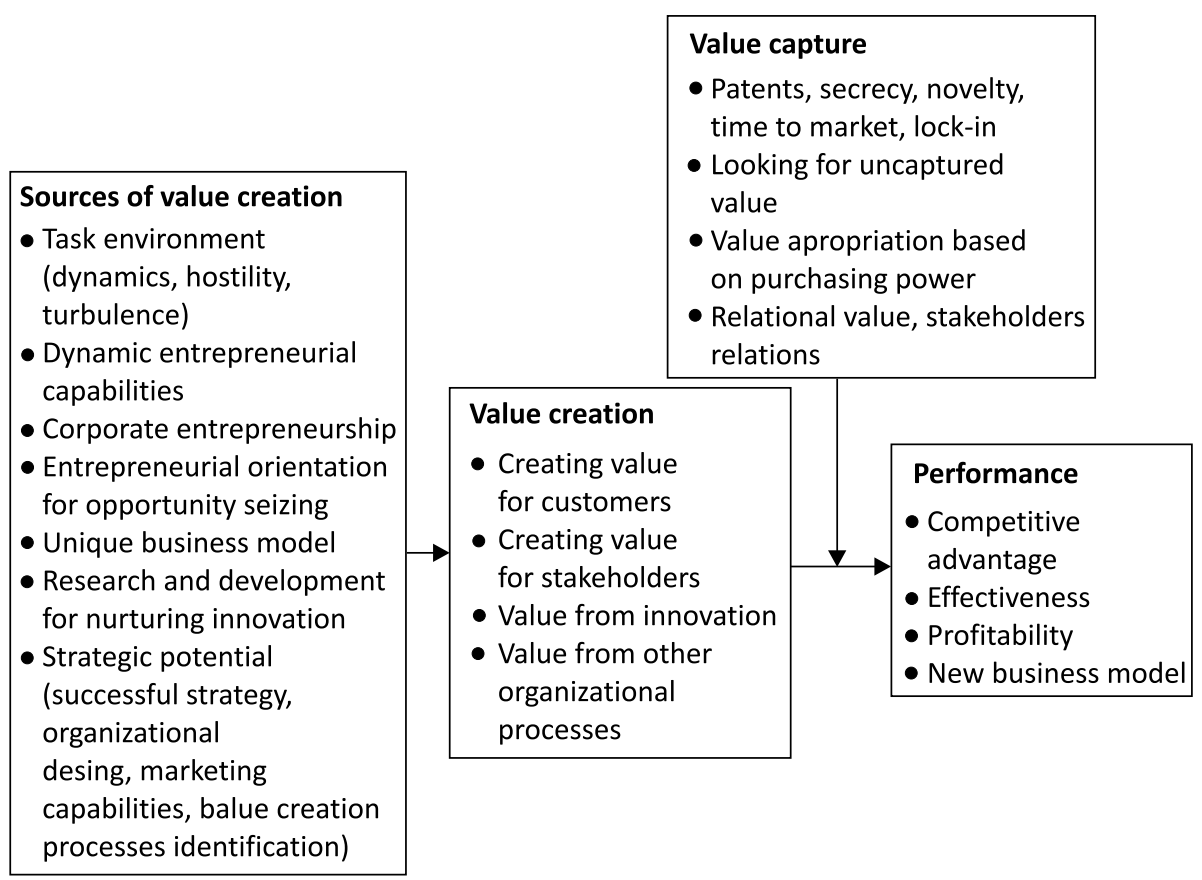

Figure 1. The framework for strategizing value creation and value capture

Source: own study.

We are aware, that the research model presented in this paper was a preliminary one, not taking into consideration all the variables presented in the literature. We concentrated just on the relations between the strategic potential, corporate entrepreneurship and value creation. Following the theoretical basics, for the future research we would like to propose a more comprehensive model (Fig. 1) that will embrace contextual factors (task environment), strategic potential, 
dynamic capabilities, business model, and the potential of organizations not just to create value, but also the capability to capture value. The strategic potential assures not only how much value is being created, but also how much of the created value the company is able to retain. We hope, that we will be able to explain what precisely influences value creation and value capture processes in the entrepreneurial organizations.

\section{CONCLUSIONS}

This paper has attempted to identify the relations between the strategic potential of organizations, corporate entrepreneurship and the value creating processes. Through the preliminary research carried out among businesses in Poland, some findings have been spotted. First, the researched organizations have some extent of strategic potential to create value. They formulate and implement successful strategies, even though the strategic choices they make do not directly translate into innovations. The organizations know how to identify the places of creating value in the value chain, however they do not always know how to capture the value, or how to extract the value before the stakeholders do. Many of them possess the marketing capabilities to offer value (know-how about customers and important competitors, segmentation skills, price and advertising policy, unique selling proposition). The majority of the researched organizations seek to incorporate the strategic design of their organizations for nurturing innovation and stimulating corporate entrepreneurship (eg. by designing proper structures, knowledge management, places to work stimulating creativity, etc.).

Second, the strategic potential translates directly into the level of corporate entrepreneurship. In case of the two models we have identified, the relations between strategic potential and corporate entrepreneurship was relatively high and statistically significant. This suggests, that the researched organizations benefit from their strategic potential to stimulate entrepreneurship as a source of value creation.

Third, we found no direct influence of the strategic potential and corporate entrepreneurship onto the value creating processes. We posit, that there might be some other variables explaining the value creation in the researched organizations like task environment, 
dynamic capabilities, unique business model, research and development structures nurturing innovation. These findings also suggest, that some other measures might be incorporated to assess both corporate entrepreneurship and value creation processes. We have used a limited set of items for both constructs, which is a limitation of the results presented here. Finally, we believe, that the strategic potential and the level of corporate entrepreneurship do not just translate into the level of the value created, but moreover into the value the organization is able to retain, protect, or capture.

Our efforts contribute to the literature in the following ways. First, the research extends strategic management theory by exploring the possibility of linking strategic potential, entrepreneurship, and the construct of value creation. Second, the insights developed here advance strategic management thinking by indicating the importance of the sources of value creation. In this sense our perspective is more comprehensive than value creation approaches used in prior studies that mostly focus on economics, finance, marketing, while the lenses of strategic management and corporate entrepreneurship were sometimes overlooked.

We are aware, that the preliminary results of our analysis suggest a need for further theoretical development of the underlying mechanisms which link strategic potential with entrepreneurship as well as value creation and value capture. Addressing these issues in the future research might overcome the limitations we have identified.

\section{REFERENCES}

Acs, Z.J. \& Audretsch, D.B. (2003). Handbook of Entrepreneurship Research. Boston, Dordrecht, London: Kluwer Academic Publishers.

Afuah, A. (2000). How much do your co-opetitors' capabilities matter in the face of technological change? Strategic Management Journal, 21(3), 397-404.

Alvarez, S. \& Barney, J. (2004). Organizing rent generation and appropriation: Toward a theory of the entrepreneurial firm. Journal of Business Venturing, 19(5), 621-635.

Amit, R. \& Zott, Ch. (2001). Value creation in e-business. Strategic Management Journal, 22, 493-520.

Anderson, B.S., Kreiser, P.N., Kuratko, D.F., Hornsby, J.S. \& Eshima, Y. (2015). Reconceptualizing entrepreneurial orientation. Strategic Management Journal, 36(10), 1579-1596. 
Antoncic, B. \& Hisrich, R.D. (2003). Privatization, corporate entrepreneurship and performance: Testing a normative model. Journal of Developmental Entrepreneurship, 8(3), 197-218.

Balka, K., Raasch, C. \& Herstatt, C. (2014). The effect of selective openness on value creation in user innovation communities. Journal of Product Innovation Management, 31(2).

Barney, J. \& Arikan, A. (2001). The Resource-Based View: Origins and Implications. Handbook of Strategic Management. Oxford: Blackwell Publishing.

Bilton, C. \& Cummings, S. (2010). Creative Strategy: Reconnecting Business and Innovation. Chichester: John Wiley and Sons.

Blyler, M. \& Coff, R. (2003). Dynamic capabilities, social capital and rent appropriation: Ties that split pies. Strategic Management Journal, 24(7), 677-686.

Bowman, C. \& Ambrosini, V. (2010). How value is created, captured and destroyed. European Business Review, 22(5), 479-495.

Brandenburger, A. \& Stuart, H. (1996). Value-based business strategy. Journal of Economics \& Management Strategy, 5, 5-24.

Brown, T.E., Davidsson, P. \& Wiklund, J. (2001). An operationalization of Stevenson's conceptualization of entrepreneurship as opportunity-based firm behaviour. Strategic Management Journal, 22.

Chatain, O. \& Zemsky, P. (2011). Value creation and value capture with frictions. Strategic Management Journal, 32, 1206-1231.

Chatain, O. (2010). Value creation, competition, and performance in buyer-supplier relationships. Strategic Management Journal, 32, 76-102.

Chen, M. \& Miller, D. (2015). Reconceptualizing competitive dynamics: A multidimensional framework. Strategic Management Journal, 36(5), 758-775.

Chen, M.J. \& MacMillan, I.C. (1992). Nonresponse and delayed response to competitive moves: The roles of competitor dependence and action irreversibility. Academy of Management Journal, 35, 359-370.

Chesbrough, H. \& Rosenbloom, R.S. (2002). The role of the business model in capturing value from innovation: Evidence from Xerox Corporation's technology spinoff companies. Industrial and Corporate Change, 11(3), 529-555.

Cooper, R.G. (2011). Winning at New Products. Creating Value Through Innovation. New York: Basic Books.

DeSarbo, W.S., Di Benedetto, C.A., Song, M. \& Sinha, I. (2005). Revisiting the miles and snow framework: Uncovering interrelationships between strategic types, capabilities, environmental uncertainty and firm performance. Strategic Management Journal, 26, 47-74.

Ethiraj, S.K., Kale, P., Krishnan, M.S. \& Singh, J.V. (2005). Where do capabilities come from and how do they matter? A study in the software industry. Strategic Management Journal, 26(1), 25-45. 
Fischer, T. (2011). Managing Value Capture. Heidelberg: Gabler Verlag-Springer. Foss, N.J. \& Lindenberg, S. (2013). Microfoundations for strategy: A goal-framing perspective on the drivers of value creation. Academy of Management Perspective, 27(2), 85-102.

Garcia-Castro, R. \& Aguilera, R.V. (2015). Incremental value creation and appropriation in a world with multiple stakeholders. Strategic Management Journal, 36, 137-147.

Gauthier, C. (2014). Creating value while avoiding its destruction through R\&D management and innovation. R\&D Management, 44(2), 171.

Gelei A. (2012). Capability-based value creation in Hungarian automotive supply chains. The IMP Journal, 6(2), 135-153.

George, B.A. (2011). Entrepreneurial orientation: Theoretical and empirical examination of the consequences of differing construct representations. Journal of Management Studies, 48, 1291-1313.

Germany, R. \& Muralidharan, R. (2001). The three phases of value capture: Finding competitive advantage in the information age. Strategy \& Business, 1(22), 1-19.

Grimpe, Ch. \& Hussinger, K. (2013). Resource complementarity and value capture in firm acquisitions: The role of intellectual property rights. Strategic Management Journal, 35, 1762-1780.

Helfat, C.E. (1997). Know-how and asset complementarity and dynamics capability accumulation: The case of R\&D. Strategic Management Journal, 18(5), 339-360.

Hoffmann, A. \& Henkel, J. (2015). Value capture in hierarchically organized value chains. Academy of Management Proceedings, January 2015 (Meeting Abstract Supplement), 14194.

Hornsby, J.S., Kuratko, D.F., Holt, D.T. \& Wales, W.J. (2013). Assessing a measurement of organizational preparedness for corporate entrepreneurship. Journal of Product Innovation Management, 30(5), 937-955.

Horth, D.M. \& Vehar, J. (2014). Becoming a leader who fosters innovation (white paper). Center for Creative Leadership, 2-25.

James, S.D., Leiblein, M.J. \& Lu, S. (2013). How firms capture value from their innovations. Journal of Management, 39(5), 1123-1155.

Johns, J. (2005). Video games production networks: Value capture, power relations and embeddedness. Journal of Economic Geography, 6, 151-180.

Kivleniece, I. \& Quelin, B.V. (2012). Creating and capturing value in public-private ties: A private actor's perspective. Academy of Management Review, 37(2), 272-299.

Kraemer, K.L., Linden, G. \& Dedrick J. (2008). Capturing value in global networks: Apple's iPad and iPhone. Industry Studies 2008 Annual Conference, Boston, MA. 
Kuratko, D.F., Audretsch, D.B. (2009). Strategic entrepreneurship: Exploring different perspectives of an emerging concept. Entrepreneurship Theory \& Practice, $33(1), 1-17$.

Lepak, D.P., Smith, K.G. \& Taylor, M.S. (2007). Value creation and value capture: A multilevel perspective. Academy of Management Review, 32(1), 180-194.

Letaifa, S.B. (2014). The uneasy transition from supply chains to ecosystems: The value-creation/value-capture dilemma. Management Decisions, 52(2), 278-295.

Lieberman, M.B., Balasubramanian, N. \& Garcia-Castro, R. (2013). Value Creation and Appropriation in Firms: Conceptual Review and a Method for Measurement. Retrieved from: http://ssrn.com/abstract=2381801.

Lieberman, M.B. \& Balasubramanian, N. (2007). Measuring value creation and its distribution among stakeholders of the Firm. Proceedings of the Academic Management Annual Meeting, 1-43.

Lindenberg, S. \& Foss, N.J. (2011). Managing joint production motivation: The role of goal framing and governance mechanisms. Academy of Management Review, 36(3), 500-525.

Livengood, R. \& Reger, R. (2010). That's our turf! Identity domains and competitive dynamics. Academy of Management Review, 35, 48-66.

Lumpkin, G.T. \& Dess, G.G. (1996). Clarifying the entrepreneurial orientation construct and linking it to performance. Academy of Management Review, 21(1), 135-172.

MacDonald, G. \& Ryall, M.D. (2004). How do value creation and competition determine whether a firm appriopriates value? Management Science, 50(10), 1319-1333.

Martelo-Iandroguez, S. \& Cepeda-Carrion, G. (2013). Trying to find a link between knowledge management processes and value appropriation. In: Euram: Waves and Winds of Strategic Leadership for Sustainable Competitiveness. Brussels: European Academy of Management.

Michel, S. (2014). Capture more value. Harvard Business Review, 10.

Miller, D. (1983). The correlates of entrepreneurship in three types of firms. Management Science, 29.

Morris, M.H., Kuratko, D.F. \& Covin, J.G. (2011). Corporate Entrepreneurship \& Innovation ( $3^{\text {rd }}$ edition). Cengage: South-Western Publishers.

Morrow, J.L. Jr, Sirmon, D.G., Hitt, M.A. \& Holcomb, T.R. (2007). Creating value in the face of declining performance: Firm strategies and organizational recovery. Strategic Management Journal, 28(3), 271-283.

Peteraf, M.A. \& Barney, J.B. (2003). Unravelling the resource-based tangle. Managerial and Decision Economic, 24, 305-323.

Pitelis, Ch.N. (2009), The co-evolution of organizational value capture, value creation and sustainable advantage. Organization Studies, 30(10), 1115-1139. 
Priem, R.L. \& Swink, M. (2012). Demand-side perspective on supply chain management. Journal of Supply Chain Management, 48(2), 7-13.

Rass, M., Dumbach, M., Danzinger, F., Bullinger, A.C. \& Moeslein, K.M. (2013). open innovation and firm performance: The mediating role of social capital. Creativity and Innovation Management, 22(2), 177-194.

Rauch, A., Wiklund, J., Lumpkin, G.T. \& Frese, M. (2009). Entrepreneurial orientation and business performance: An assessment of past research and suggestions for the future. Entrepreneurship Theory and Practice, 33(3), 761-787.

Renko, M., Carsrud, A., \& Brannback, M. (2009). The effect of a market orientation, entrepreneurial orientation, and technological capability on innovation: A study of young biotechnology ventures in the United States and Scandinavia. Journal of Small Business Management, 47(3), 331-369.

Sirmon, D.G., Hitt, M.A. \& Ireland, R.D. (2007). Managing firm resources in dynamic environments to create value: Looking inside the black box. Academy of Management Review, 32(1), 273-292.

Skilton, P.F. (2014). Value creation, value capture, and supply chain structure: Understanding resource-based advantage in a project-based industry. Journal of Supply Chain Management, 50(3), 74-93.

Stevenson, H.H. \& Jarillo, J.C. (1990). A paradigm of entrepreneurship: Entrepreneurial management. Strategic Management Journal, 11.

Subramanian, R., San Vicente Portes, L. \& Xia, J. (2014). Value capture in international strategic alliances: An empirical analysis using the event study methodology. Management, Northeast Business \& Economics Association, 566.

Talaja, A. (2012). Testing VRIN framework: Resource value and rareness as sources of competitive advantage and above average performance. Management, 17(2), 51-64.

Teece, D.J. (2007). Explicating dynamic capabilities: The nature and microfoundations of (sustainable) enterprise performance. Strategic Management Journal, 28(13), 1319-1350.

Tescari, F.C. \& Ledur Brito, L.A. (2016). Value creation and capture in buyer-supplier relationships: A new perspective. Revista de Administração de Empresas, $56(5), 474-488$.

Venkatraman, N. \& Henderson, J.C. (2008). Four vectors of business model innovation: Value capture in a network era. In: D.C. Pantaleo, N. Pal (eds.), From Strategy to Execution: Turning Accelerated Global Change into Opportunity (pp. 259-280), London: Springer.

Verdin, P. \& Tackx, K. (2015). Are you creating or capturing value? A dynamic framework for sustainable strategy. $M-R C B G$ Working Paper Series, 36, 1-19. 
West, J. (2007). Value capture and value networks in open source vendor strategies. Proceedings of the Hawai'i International Conference on System Sciences (HICSS-40), January, 3-7, Waikola, Hawai.

Wiklund, J., Shepherd, D. (2005). Entrepreneurial orientation and small business performance: A configurational approach. Journal of Business Venturing, 20, 71-91.

Yang, M., Vladimirova, D. \& Evans, S. (2017). Creating and capturing value through sustainability, Research-Technology Management, 60(3), 30-39. DOI: 10.1080/08956308.2017.1301001.

Zahra, S., Jennings, D.F. \& Kuratko, D.F. (1999). Antecedents and consequences of firm-level entrepreneurship: The state of the field. Entrepreneurship Theory \& Practice, 24, 45-66. 


\section{POTENCJAK STRATEGICZNY I PRZEDSIĘBIORCZOŚĆ ORGANIZACYJNA W PROCESACH TWORZENIA I ZATRZYMYWANIA WARTOŚCI}

Celem niniejszego artykułu jest spojrzenie na źródła tworzenia wartości w organizacjach. W szczególności uwaga została skupiona na potencjale strategicznym organizacji ożywiajacym generowanie innowacyjnych idei oraz przedsiębiorczości organizacyjnej. Wskazano też na znaczenie budowy takiego potencjału strategicznego, który nie tylko przełoży się na tworzenie wartości, ale także pozwoli zatrzymać lub przechwycić znaczna jej część. W artykule zaprezentowano ramy teoretyczne zarysowujące relacje pomiędzy wymiarami potencjału strategicznego, przedsiębiorczościa organizacyjną i wynikami organizacji w postaci wytworzonej wartości. Przedstawiono również fragment badań empirycznych przeprowadzonych wśród organizacji w Polsce, z których wynika, że o ile potencjał strategiczny i przedsiębiorczość organizacyjna sa dobrze skorelowane, o tyle sekwencja ta tylko częściowo przekłada się na tworzenie wartości. Sugeruje to, że procesy tworzenia i zatrzymywania wartości w organizacjach powinny być wyjaśniane przez większą liczbę zmiennych. Artykuł jest wynikiem projektu naukowego pt. „Tworzenie i przechwytywanie wartości w organizacjach przedsiębiorczych" finansowanego przez NCN (grant nr 2015/17/B/HS4/00935).

Słowa kluczowe: tworzenie wartości, zatrzymywanie wartości, przedsiębiorczość. 